\title{
Four additional Hepatozoon species (Apicomplexa: Hepatozoidae) from north Florida ratsnakes, genus Pantherophis
}

\author{
Sam R. Telford, Jr. ${ }^{1}$, Paul E. Moler ${ }^{2}$ and Jerry F. Butler ${ }^{3}$ \\ ${ }^{1}$ The Florida Museum of Natural History, University of Florida, Gainesville, Florida 32611, USA; \\ ${ }^{2}$ Florida Fish and Wildlife Conservation Commission, 1105 SW Williston Road, Gainesville, Florida 32601, USA; \\ ${ }^{3}$ Department of Entomology and Nematology, Institute of Food and Agricultural Sciences, University of Florida, P.O. Box 110620, \\ Gainesville, Florida 32611-0620, USA
}

\begin{abstract}
Records from a colubrid host are reported for Hepatozoon horridus, described originally from a viperid snake. Hepatozoon horridus in Pantherophis guttatus (Colubridae) has gamonts $14-18.0$ by $4.0-5.5 \mu \mathrm{m}$, with length by width (LW) $60-99 \mu \mathrm{m}^{2}$, and L/W ratio 2.5-3.9. Spherical to elongate, usually ovoid oocysts with L/W ratio 1.0-3.7 contain 16-160 spherical to usually ovoid sporocysts $15-31$ by $14-26 \mu \mathrm{m}$, with L/W ratio 1.0-1.4, that contain 5-24 sporozoites. Two additional Hepatozoon species are described from ratsnakes in north Florida. Hepatozoon quadrivittata $\mathrm{n}$. sp. from Pantherophis obsoletus quadrivittatus has gamonts 12-17 by 4-6 $\mu \mathrm{m}$, LW 56-102 $\mu \mathrm{m}^{2}$, and L/W ratio 2.6-3.8. Nearly spherical oocysts with L/W 1.0-1.1 contain 5-227 spherical to slightly ovoid sporocysts $20-48$ by $19-45 \mu \mathrm{m}$, with $\mathrm{L} / \mathrm{W}$ ratio $1.0-1.4$, that contain $13-48$ sporozoites. Hepatozoon spiloides $\mathrm{n}$. sp. from Pantherophis obsoletus spiloides forms gamonts $12-15$ by $4-5 \mu \mathrm{m}$ with $\mathrm{LW} 48-75 \mu \mathrm{m}^{2}$ and $\mathrm{L} / \mathrm{W}$ ratio $2.6-3.5$. Occasionally rounded but usually elongate oocysts, with $\mathrm{L} / \mathrm{W}$ ratio $1.0-2.7$, contain $5-21$ spherical to elongate sporocysts $28-43$ by $18-35 \mu \mathrm{m}$, L/W ratio 2.5-3.9. In the distinctive Hepatozoon sp. present in Pantherophis obsoletus spiloides, gamonts are 13-17 by 5-10 $\mu \mathrm{m}$, with LW 75-140 $\mu \mathrm{m}^{2}$ and L/W ratio 1.4-3.0. Infected erythrocytes are always distorted and enlarged on average 2.5 times the size of uninfected cells, with nuclei enlarged by one-third and broadly elongated. Gamonts often stained deep blue, and cytoplasm of erythrocytes infected with mature gamonts was always dehemoglobinized. Sporogony could not be obtained in three feedings by hundreds of Aedes aegypti, which usually died within the first $24-48 \mathrm{hr}$.
\end{abstract}

Keywords: blood parasites, hemogregarines, Hepatozoon horridus, Hepatozoon quadrivittata, Hepatozoon spiloides, Pantherophis guttatus, Pantherophis obsoletus quadrivittatus, Pantherophis obsoletus spiloides, Florida

Hemogregarines are the most common hemoparasites of snakes. Species of Hepatozoon Miller, 1908 have been described from all groups of reptiles, crocodilians, turtles, lizards, and the tuatara (Smith 1996, Telford 2009). Over 300 species have been described, sadly only from the gamonts found in blood cells in most cases, and too often just on the basis of infecting a different host species. Generic and species identity can be established only from sporogonic characters present in a capable invertebrate vector, or from genomic studies (Ball et al. 1967, Mathew et al. 2000). Transmission occurs when a vector or first vertebrate host is ingested by a suitable predator host or through bite (Telford 2009). Only four Hepatozoon species have been proven to be transmitted by ingestion of an infected vertebrate intermediate host (Landau et al. 1972, Smith et al. 1994, Telford et al. 2001, Sloboda et al. 2008), and it is probable that most species infect a single vertebrate host in their life cycles.

The very diverse snake fauna of Florida contains two species of ratsnakes (Colubridae) previously placed in the genus Elaphe Fitzinger in Wagler, 1833, but now assigned to Pantherophis Fitzinger, 1843, based upon DNA characteristics (Utiger et al. 2002). Further, Burbrink (2001) pro- posed to recognize three species within the ratsnake, Pantherophis obsoletus Say, complex. This classification has not, however, yet won general acceptance and will probably face further changes in the future. Therefore, the more familiar polytypic $P$. obsoletus is used below.

The ratsnakes are a common and conspicuous component of the Florida reptilian fauna and their often semiarboreal habits expose them even more than terrestrial snakes to the rich mosquito fauna that shares their habitat, resulting in the presence of four Hepatozoon species apparently specific to ratsnakes, as well as to common infection by the eurytopic H. sauritus Telford, Ernst, Clark et Butler, 2004 (Telford et al. 2004) and H. eurytopis Telford, 2010 from south Florida Pantherophis guttatus (L.) (see Telford 2010). Only H. sauritus has been reported from north Florida ratsnakes (Telford et al. 2004), and $H$. guttata Telford, Butler et Telford, 2002 is only known from south Florida P. guttatus (Telford et al. 2002a).

In the present paper, Hepatozoon horridus Telford, Moler et Butler, 2008, described from a viperid snake, is redescribed from a colubrid host, two new species are described from North Florida, and a fourth species for which sporogony could not be obtained is described but not named. 


\section{MATERIALS AND METHODS}

The collection and staining procedures of blood samples, details and processing of sporogony experiments, and taxonomic characters used are described elsewhere by Telford et al. (2001). Staining characteristics produced by Giemsa stain were typical for Hepatozoon species except where indicated. The nucleus position was estimated from the slightly narrower end of the gamont. Prevalence is based upon the entire sample of ratsnakes examined from the particular area between 1990-2011. All measurements, obtained by a calibrated ocular micrometer, are in $\mu \mathrm{m}$ with means and SD followed by ranges in parentheses, or in the case of LW (length by maximum width) values, $\mu \mathrm{m}^{2}$. Comparisons were done when necessary by one-way ANOVA on transformed data $(\log \mathrm{x}+1)$ with significance $P \leq 0.05$. Differences noted below (smaller, larger, greater, less, etc.) were statistically significant; the term "similar to" indicates that significant differences were not present. Hapantotype slides were deposited in the U.S. National Parasite Collection (USNPC), Beltsville, Maryland; other hapantotype slides were deposited with the Telford collection at the Manter Museum of Parasitology, University of Nebraska State Museum, Lincoln, Nebraska (HWMLPC).

\section{RESULTS}

Hepatozoon horridus was described from a viperid snake. With its presence now known to occur in a colu- brid snake, it is redescribed here from the colubrid host to demonstrate that no morphological differences exist due to host family.

\section{Redescription of Hepatozoon horridus Telford,} Moler et Butler, 2008

Figs. 1-12

Gamonts: Mature gamonts (Figs. 1-4) $15.7 \pm 0.8$ by $4.8 \pm 0.5 \mu \mathrm{m} \quad(14-18$ by $4.0-5.5, \mathrm{~N}=25)$, LW $75.9 \pm 10.1 \mu \mathrm{m}^{2}(60-99)$, and $\mathrm{L} / \mathrm{W}$ ratio $3.3 \pm 0.4(2.5-3.9)$. Nuclei usually situated in second quarter of gamont $(68 \%)$ or extend into first quarter, $4.6 \pm 0.6$ by $4.1 \pm 0.4 \mu \mathrm{m}(3.5$ 6.5 by $3.0-4.5)$, with LW $18.9 \pm 4.0 \mu \mathrm{m}^{2}(12-29)$. Infected erythrocytes slightly longer than uninfected cells with size (LW) on average 13\% larger; nuclei always displaced, but overall size similar to uninfected cells. Host cells not dehemoglobinized.

Sporogonic stages: In Aedes aegypti, spherical to elongate, usually ovoid oocysts (Figs. 5-9), $159 \pm 52$ by $153 \pm 54 \mu \mathrm{m}(39-243$ by $12-240, \mathrm{~N}=46)$, with $\mathrm{L} / \mathrm{W}$ ratio $1.1 \pm 0.4(1.0-3.7)$, contained $16-160(\mathrm{~N}=22)$ spherical to usually ovoid sporocysts (Figs. 10, 11), $23 \pm 4$ by $20 \pm 3.5 \mu \mathrm{m}(15-31$ by $14-26, \mathrm{~N}=52)$, with rounded residual body visible. Sporocyst L/W ratio $1.1 \pm 0.1(1.0-1.4)$, and contained $13 \pm 4(5-24, \mathrm{~N}=24)$ sporozoites (Fig. 12).

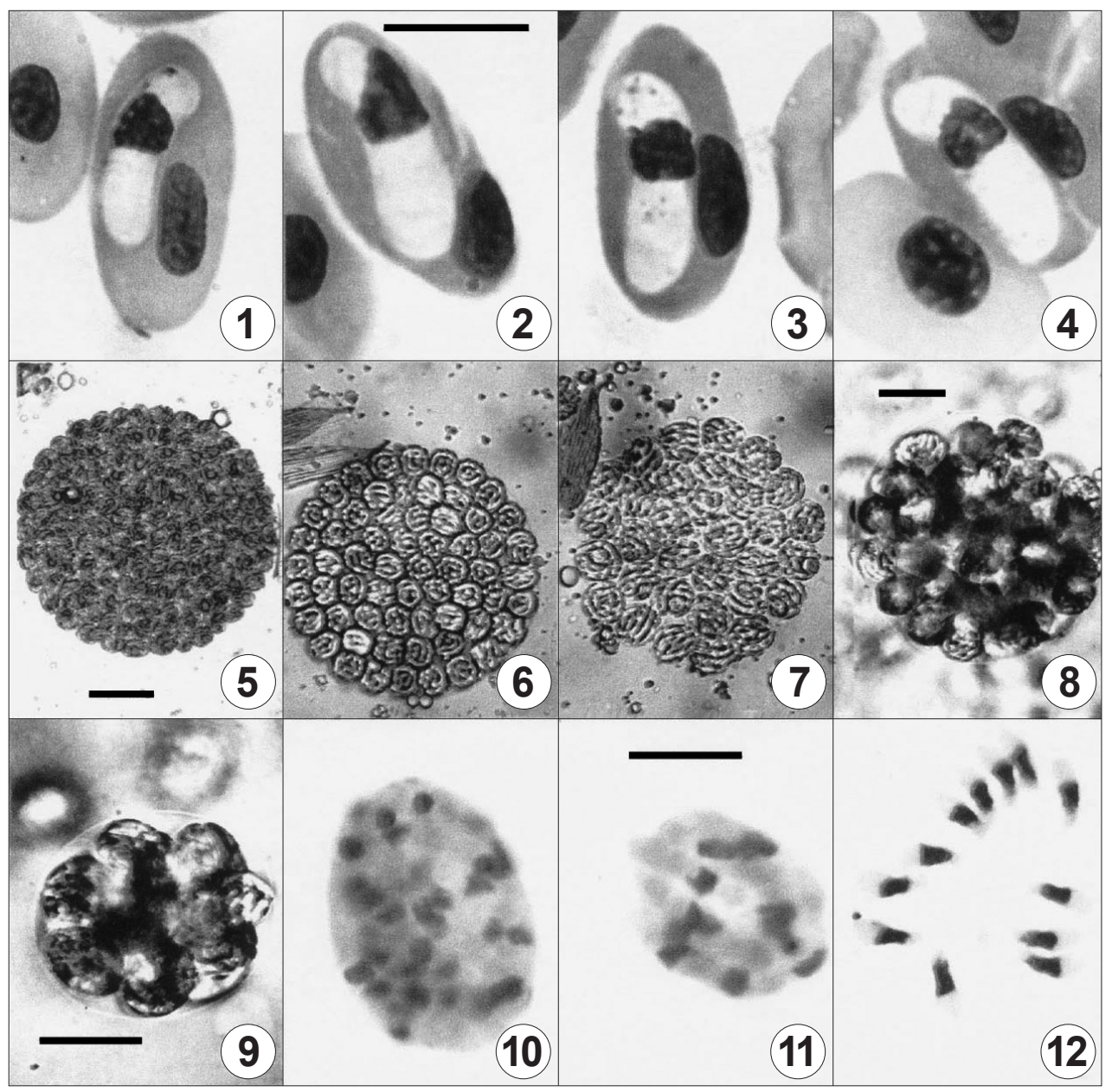

Figs. 1-12. Hepatozoon horridus from Pantherophis guttatus, from Baker County, Florida. 1-4. Mature gamonts. 5-12. Sporogonic stages in Aedes aegypti. 5-9. Fresh oocysts. Sporocysts (Fig. 6) flattened. 10, 11. Stained sporocysts. 12. Sporozoites. Scale bar in Fig. $5=20 \mu \mathrm{m}$, remainder $10 \mu \mathrm{m}$. 


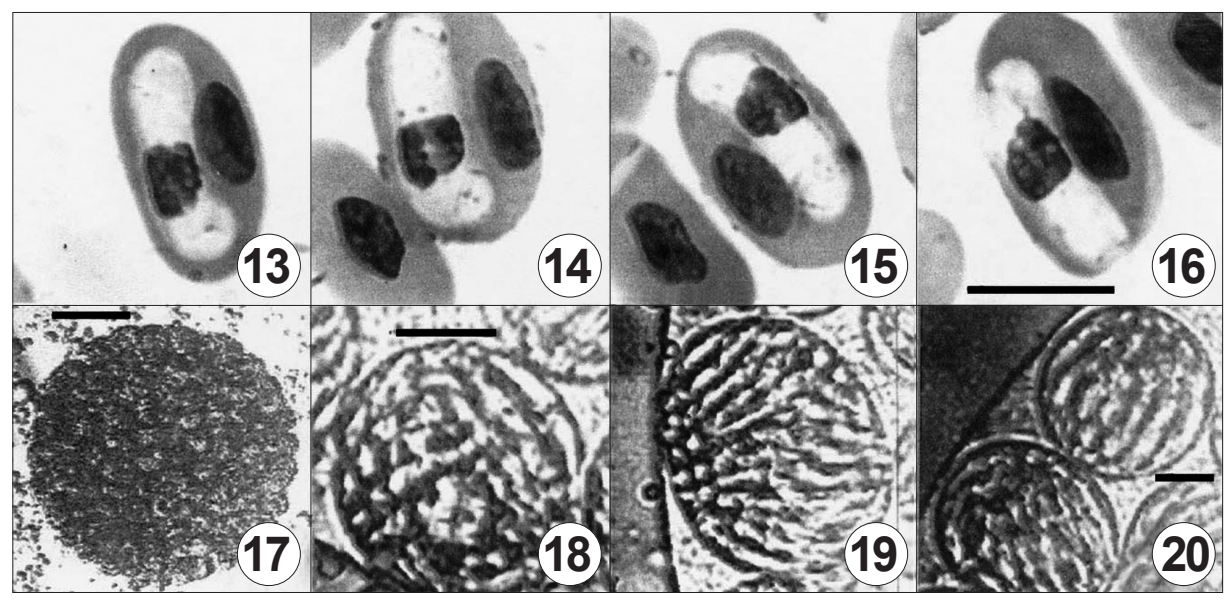

Figs. 13-20. Hepatozoon quadrivittata sp. n. from Pantherophis obsoletus quadrivittatus, Marion County, Florida. 13-16. Mature gamonts. 17-20. Sporogonic stages in Aedes aegypti. 17. Fresh oocyst. 18-20. Fresh sporocysts within oocyst. Scale bar in Fig. $17=20 \mu \mathrm{m}$, remainder $10 \mu \mathrm{m}$.

Type host: Crotalus horridus Linnaeus (Serpentes: Viperidae). Other hosts: Pantherophis guttatus (Linnaeus) (Serpentes: Colubridae).

Type locality: Florida, USA, Baker County, State Road $250,3.6 \mathrm{~km}$ west of Taylor $\left(30^{\circ} 29.532^{\prime} \mathrm{N}, 82^{\circ} 18.232^{\prime} \mathrm{W}\right)$.

Prevalence: One of eight, overall, in $C$. horridus, three of five from P. guttatus in Baker and Columbia counties, Florida. Site of infection: Erythrocytes.

Material deposited: Hapantotype blood films in the U.S. National Parasite Collection, Beltsville, Maryland (USNPC 99676, 104884; stained dissections containing oocysts USNPC 99678), other hapantotypes deposited with the Telford Collection at the Manter Museum of Parasitology, University of Nebraska State Museum, Lincoln, Nebraska. Symbiotype host not deposited.

Etymology: The specific name reflects the type host specific name.

Remarks. Only two Hepatozoon species in the very diverse snake fauna of Florida have been proven to infect naturally snake hosts of two families, Colubridae and Viperidae: H. sauritus (Telford et al. 2008) and H. horridus, reported here, neither of which differs significantly in gamont or sporogonic characters from infection in the type host species.

\section{Hepatozoon quadrivittata sp. $\mathrm{n}$.}

Figs. 13-20

Gamonts: Mature gamonts (Figs. 13-16) $15.7 \pm 0.9$ by $5.0 \pm 0.5 \mu \mathrm{m}(12-17$ by $4-6, \mathrm{~N}=25)$, with $\mathrm{LW}$ $77.0 \pm 11.1 \mu \mathrm{m}^{2}(56-102)$, and $\mathrm{L} / \mathrm{W}$ ratio $3.1 \pm 0.28(2.6-$ 3.8 ), nuclei $4.9 \pm 0.7$ by $4.2 \pm 0.6 \mu \mathrm{m}$ ( $4-6.5$ by $3-5.5)$, $\mathrm{LW}$ $20.3 \pm 5.0 \mu \mathrm{m}^{2}(13-36)$. Nuclei situated in second quarter of gamont $(72 \%)$ or extend from second quarter into first $(12 \%)$ or third quarter $(16 \%)$. Infected erythrocytes noticeably broadened, longer and wider than uninfected cells, with $18 \%$ greater size (LW). Host cell nuclei usually displaced laterally, but similar in size to those of uninfected erythrocytes. Infected erythrocytes uncommonly slightly dehemoglobinized (32\%).
Sporogonic stages: In Aedes aegypti fed upon experimental infection of Pantherophis obsoletus quadrivittatus, nearly spherical oocysts formed (Fig. 17), $93 \pm 48$ by $90 \pm 48 \mu \mathrm{m}(21-282$ by $20-282, \mathrm{~N}=34)$, with $\mathrm{L} / \mathrm{W}$ $1.0 \pm 0.04(1.0-1.1)$, and contained 5-227 spherical to usually slightly ovoid sporocysts (Figs. 18-20), $30 \pm 5$ by $27 \pm 5 \mu \mathrm{m}(20-48$ by $19-45, \mathrm{~N}=59)$, with prominent, rounded residual body present. Sporocysts with $\mathrm{L} / \mathrm{W}$ ratio $1.1 \pm 0.7(1.0-1.4)$, and contained $26 \pm 8.5(13-48, \mathrm{~N}=19)$ sporozoites.

Type and only host: Pantherophis obsoletus quadrivittatus (Holbrook, 1836) (Serpentes: Colubridae).

Type locality: Florida, USA, Marion County, Macintosh $\left(29^{\circ} 26.56^{\prime} \mathrm{N}, 82^{\circ} 13.19^{\prime} \mathrm{W}\right)$.

Prevalence: Six of 18 P. obsoletus from Marion and Alachua counties, Florida were infected.

Site of infection: Erythrocytes.

Material deposited: Hapantotype blood film in the U.S. National Parasite Collection, Beltsville, Maryland (USNPC 104885). Other hapantotypes deposited with the Telford Collection at the Manter Museum of Parasitology, University of Nebraska State Museum, Lincoln, Nebraska. Symbiotype host not deposited.

Etymology: The specific name reflects the type host subspecific name.

\section{Hepatozoon spiloides sp. $\mathrm{n}$.}

Figs. 21-36

Gamonts: Mature gamonts (Figs. 21-24) $13.7 \pm 0.6$ by $4.8 \pm 0.4 \mu \mathrm{m}(12-15$ by $4-5, \mathrm{~N}=25)$, with $\mathrm{LW}$ $65.4 \pm 6.4 \mu \mathrm{m}^{2}(48-75)$, and $\mathrm{L} / \mathrm{W}$ ratio $2.9 \pm 0.22(2.6-3.5)$. Gamonts not recurved within host cell. Nucleus length $4.4 \pm 0.5$ by $3.8 \pm 0.4 \mu \mathrm{m}(4.0-6.0$ by $3.0-4.5)$, with LW $16.7 \pm 3.2 \mu \mathrm{m}^{2}(12.0-24.0)$, situated usually in second quarter of gamont $(75 \%)$ or extending into first quarter $(16 \%)$, seldom at middle of gamont. Usually distorted, host erythrocytes larger (22\%) than uninfected cells, their nuclei similar in size. Cytoplasm of infected erythrocytes usually shows some slight dehemoglobination (88\%). 


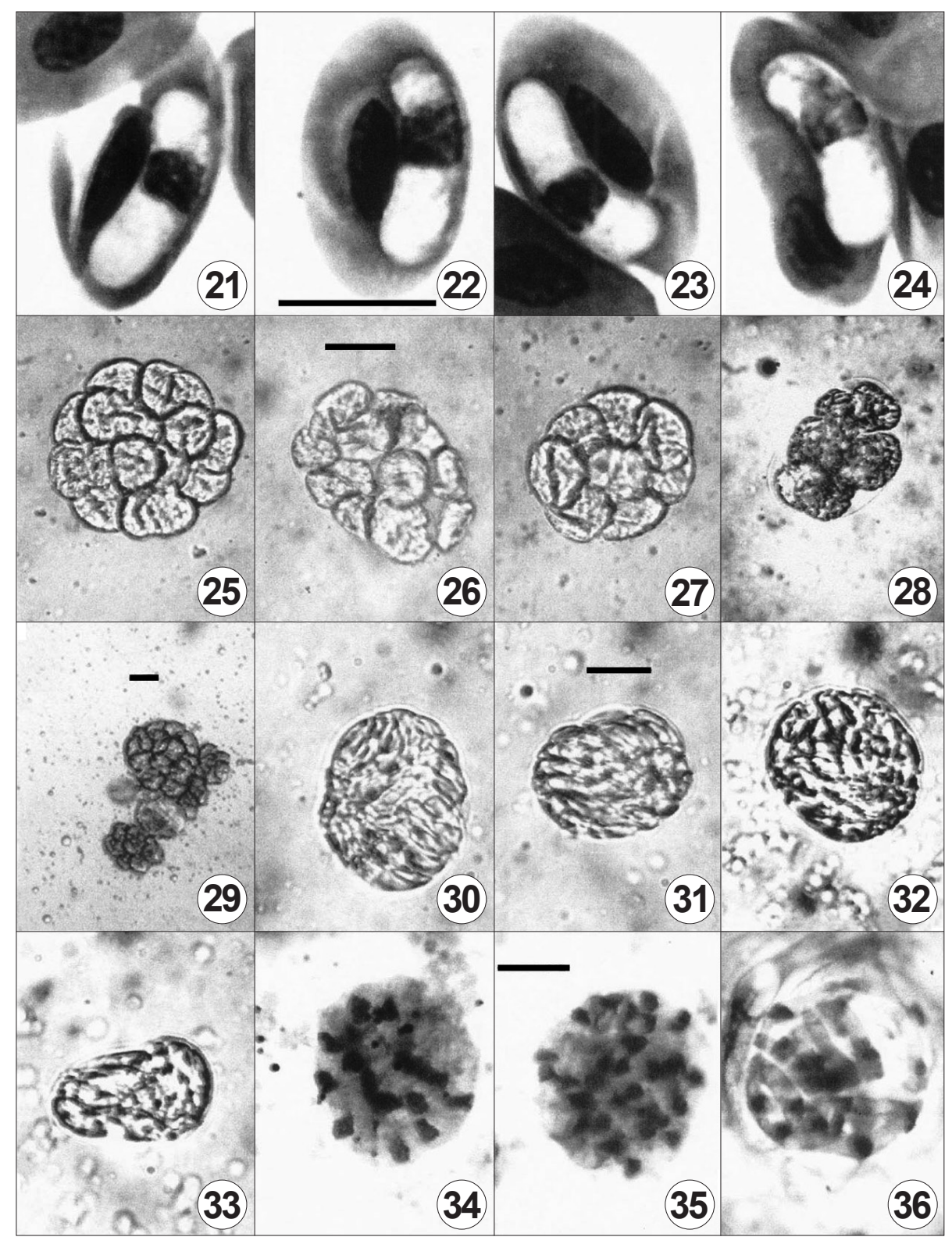

Figs. 21-36. Hepatozoon spiloides sp. n. from Pantherophis obsoletus spiloides, Wakulla County, Florida. 21-24. Mature gamonts. 25-36. Sporogonic stages in Aedes aegypti. 25-29. Fresh oocysts. 30-33. Fresh sporocysts. 34-36. Stained sporocysts. Scale bars = $20 \mu \mathrm{m}$ in Figs. 26 and 29, remainder $10 \mu \mathrm{m}$.

Sporogonic stages: In Aedes aegypti, occasionally rounded (Figs. 25, 29), but usually elongate oocysts form (Figs. 26-29) $97 \pm 24$ by $75 \pm 18.5 \mu \mathrm{m}^{2}(62-155$ by $43-$ $108, \mathrm{~N}=19)$, with $\mathrm{L} / \mathrm{W}$ ratio $1.3 \pm 0.38(1.0-2.7)$, and contain 5-21 spherical to elongate sporocysts (Figs. 30-36), $30 \pm 5.5$ by $26.5 \pm 3.0 \mu \mathrm{m}(28-43$ by $18-35, \mathrm{~N}=56)$, with $\mathrm{L} / \mathrm{W}$ ratios $1.2 \pm 0.17(1.0-1.9)$. Rounded to ovoid residual bodies present, but difficult to see. Sporocysts contain $26 \pm 7(14-44, \mathrm{~N}=25)$ sporozoites (Figs. 34-36).

Type and only host: Pantherophis obsoletus spiloides (Duméril, Bibron et Duméril, 1854) (Serpentes: Colubridae). Type 1 o cality: Florida, USA, Wakulla County, Hwy 267 $0.5 \mathrm{~km} \mathrm{~N}$ of U.S. Hwy $98\left(30^{\circ} 12.156^{\prime} \mathrm{N}, 84^{\circ} 11.172^{\prime} \mathrm{W}\right)$.

Prevale n c e: Two of two Pantherophis obsoletus in Wakulla and Jackson counties, Florida were infected.
Site of infection: Erythrocytes.

Material deposited: Hapantotype blood film in the U.S. National Parasite Collection Beltsville, Maryland (USNPC 104886); voucher - stained dissections containing oocysts and other hapantotypes - deposited with the Telford collection at the Manter Museum of Parasitology, University of Nebraska State Museum, Lincoln, Nebraska. Symbiotype host not deposited.

Et y m ology: The specific name reflects the host subspecific name.

\section{Hepatozoon sp.}

Figs. $37-44$

Gamonts: Mature gamonts (Figs. 37-42) $15.2 \pm 1.0$ by $6.0 \pm 1.0 \mu \mathrm{m}(13-17$ by $5-10, \mathrm{~N}=25)$, with $\mathrm{LW}$ $91.0 \pm 14.4 \mu \mathrm{m}^{2}(75-140)$ and $\mathrm{L} / \mathrm{W}$ ratio $2.6 \pm 0.34(1.4$ 


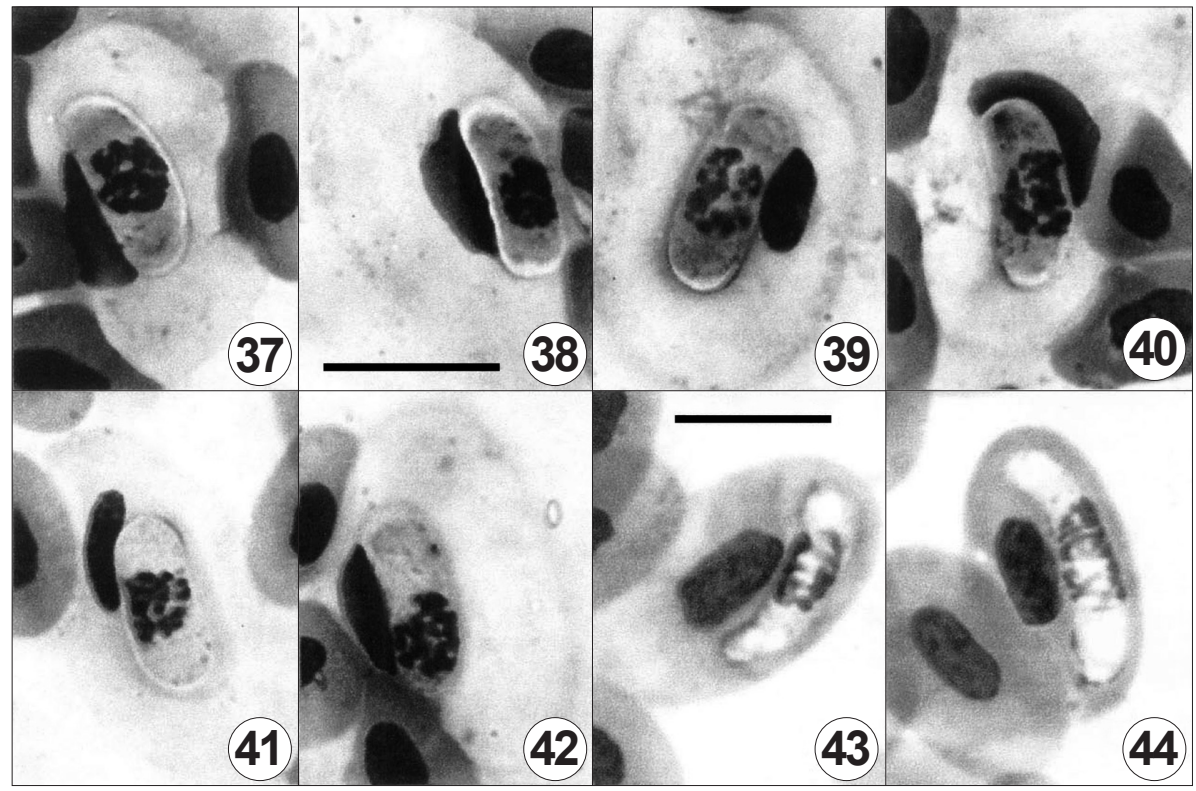

Figs. 37-44. Hepatozoon sp. from Pantherophis obsoletus spiloides, Jackson County, Florida. 37-42. Mature gamonts. 43, 44. Immature gamonts. Scale bars $=10 \mu \mathrm{m}$.

3.0). Immature gamonts elongate, slender (Figs. 43, 44). Gamonts not recurved within host cell, enclosed within prominent capsule. Nucleus $6.5 \pm 0.7$ by $4.9 \pm 0.3 \mu \mathrm{m}$ (5.0-7.5 by $4.0-5.0$ ), with LW $31.6 \pm 3.7 \mu \mathrm{m}^{2}(22.5-37.5)$, situated usually at midbody (56\%) or in second quarter of gamont (44\%). Always distorted, infected erythrocytes enlarged on average 2.5 times size of uninfected cells (Figs. 37-42), nuclei enlarged by one-third and broadly elongated. Cytoplasm of erythrocytes infected with mature gamonts always dehemoglobinized (Figs. 37-42). Host cell nuclei always displaced to lateral or lateropolar positions by gamonts. The cytoplasm of many apparently mature gamonts stained deep blue with Giemsa staining in contrast to unstained appearance characteristic of gamonts in most Hepatozoon species.

Sporogony: Experimental infections unsuccessful to obtain sporogonic stages.

Host: Pantherophis obsoletus spiloides (Duméril, Bibron et Duméril, 1854) (Serpentes: Colubridae).

L o c a lity: Florida, Jackson County, Marianna $\left(30^{\circ} 47.39^{\prime} \mathrm{N}\right.$, $\left.85^{\circ} 13.25^{\prime} \mathrm{W}\right)$.

Remarks. Although three separate feedings at about one month intervals were performed upon the host of this species and over 400 fed mosquitoes were obtained, all died before day 15, and most mortality occurred within 24 hours. The Aedes aegypti colony from which the experimental mosquitoes were obtained has served as capable hosts for 20 Hepatozoon species described from colubrid and viperid snakes of Florida. This Hepatozoon species is very similar in appearance, dimensions and effects upon host cells to the hemogregarine tentatively identified as Hepatozoon rexi Telford, 2010 from Lampropeltis getula (L.) at Cedar Key, Levy County, Florida (Telford 2010). Mosquito mortality may not be due to high parasitemia in the snake as the infection was at $<2 \%$ during each feeding.

\section{DISCUSSION}

The most widely distributed hemogregarine among Florida snake species is Hepatozoon sauritus, which is distinguished from the four species reported here by its slender gamonts that are usually longer than those of these species, with a more narrow nucleus that is positioned in the second quarter of the gamont, often extending into the first, less commonly into the third quarter. The anterior gamont end tends to be more narrow than the posterior.

In the five host species of $H$. sauritus, in Crotalus horridus and in Diadophis punctatus, the gamont length/width ratio (L/W) averages 4.0-4.5 (Telford et al. 2004, 2008; Telford, unpublished data). In the four species described here, $\mathrm{L} / \mathrm{W}$ values average 2.6-3.3. The elongate sporocysts of $H$. sauritus average 1.3-1.8 in L/W in the five hosts for which sporogony was studied, but average only 1.1-1.2 in H. quadrivittata and $H$. spiloides. The most common hemogregarine in both Pantherophis guttatus and P. obsoletus quadrivittatus in both north and south Florida populations is H. sauritus, and it was present in the host of the Hepatozoon sp. in P. obsoletus spiloides from Jackson County in northwest Florida. One of 19 P. obsoletus quadrivittatus from north Florida and one of 16 P. guttatus from south Florida were parasitized by Hepatozoon eurytopis Telford, 2010. This species, described from the kingsnake Lampropeltis getula, has gamonts that are shorter in average length, 11.2-13.1 $\mu \mathrm{m}$, with $\mathrm{L} / \mathrm{W}$ ratios $2.1-2.8$ in both natural and experimental hosts, and sporocysts that are nearly spherical, with L/W ratios 1.0-1.2, similar to those of $H$. horridus, H. quadrivittata, and H. spiloides. Hepatozoon guttata, known only from $P$. guttatus in south Florida (Telford et al. 2002a), has gamonts that average $14.6 \mu \mathrm{m}$ in length, comparable to but slightly smaller than those of H. horridus $(15.7 \mu \mathrm{m})$ and H. quadrivittata $(15.4 \mu \mathrm{m})$, and slightly larger than those in $H$. spiloides $(13.7 \mu \mathrm{m})$. The 
round to ovoid sporocysts produce on average 46 sporozoites, far more than in the three species described here from north Florida ratsnakes.

Hepatozoon spiloides has shorter and broader gamonts on average than $H$. horridus and $H$. quadrivittata. There is a similar number of sporozoites in the similarly shaped sporocysts of $H$. quadrivittata, but oocysts are more rounded than in $H$. spiloides. Hepatozoon horridus differs from both of these species by having half as many sporozoites in similarly shaped sporocysts within more rounded oocysts. Among Hepatozoon species from Florida snakes with gamont length averaging less than $15 \mu \mathrm{m}, H$. spiloides gamonts are similar in shape to those of $H$. punctatus Telford, Wozniak et Butler, 2001 and H. pictiventris Telford, Wozniak et Butler, 2001, slightly broader than in H. mansoni (Sambon and Seligmann, 1907) and H. guttata, and slightly more narrow than in $H$. sistruri Telford, Butler et Telford, 2002 (Telford et al. 2001, 2002a,b). Oocysts are more elongate in $H$. pictiventris and $H$. spiloides than in $H$. mansoni, $H$. punctatus, $H$. guttata, $H$. sistruri and $H$. polytopis (Telford et al. 2005) but sporocyst L/W ratios (1.1-
1.2) are similar among all seven species compared here. Sporozoite numbers per sporocyst are greater on average (43-46) for H. guttata, H. sistruri, and H. polytopis, fewer (20) in H. mansoni and H. punctatus than in H. spiloides. Hepatozoon pictiventris produces on average 31 sporozoites in its sporocysts.

Hepatozoon sp. from Pantherophis o. spiloides of Jackson County, reported here, was not named because sporogonic data could not be obtained (see Remarks above). In appearance it resembles Hepatozoon rarefaciens (Sambon and Seligmann, 1907) from the indigo snake, Drymarchon corais (Boie), populations in the southeastern United States, Texas, and western Mexico (Telford 2009), and possibly H. rexi from a kingsnake captured at Cedar Key, Levy County, in north-central Florida (Telford 2010). Gamonts, stout in appearance, usually dehemoglobinize the greatly enlarged host erythrocytes, and the staining reaction of many gamonts is deep blue.

Acknowledgments. We wish to thank P.E. Kaufman, Department of Entomology and Nematology, University of Florida, for making available mosquitoes from the Aedes aegypti colony.

\section{REFERENCES}

Ball G.H., Chao J., Telford JR. S.R. 1967: The life history of Hepatozoon rarefaciens (Sambon and Seligmann, 1907) from Drymarchon corais (Colubridae), and its experimental transfer to Constrictor constrictor (Boidae). J. Parasitol. 53: 897-909.

BURBRINK F.T. 2001: Systematics of the eastern ratsnake complex (Elaphe obsoleta). Herpetol. Monogr. 14: 1-53.

Landau I., Michel J.C., Chabaud A.C., Brygoo E.R. 1972: Cycle biologique d'Hepatozoon domergui; discussion sur les caractères fondamentaux d'un clcle de coccidie. Z. Parasitenk. 38: $250-270$

Mathew J.S., Van Den Bussche R.A., Ewing S.A., Malayer J.R., Latha B.R., Panciera R.J. 2000: Phylogenetic relationships of Hepatozoon (Apicomplexa: Adeleorina) based on molecular, morphologic, and life-cycle characters. J. Parasitol. 86: 366-372.

Sloboda M., Kamler M., Bulantová J., VotýpKa J., Modrý D. 2008: Rodents as intermediate hosts of Hepatozoon ayorghor (Apicomplexa: Adeleina: Hepatozoidae) from the African ball python, Python regius? Folia Parasitol. 55: 13-16.

Sмiтh T.G. 1996: The genus Hepatozoon (Apicomplexa: Adeleina). J. Parasitol. 82: 565-585.

Smith T.G., Desser S.S., Martin D.S. 1994: The development of Hepatozoon sipedon (Apicomplexa: Adeleina: Hepatozoidae) in its natural host, the Northern water snake (Nerodia sipedon sipedon), the culicine vectors, Culex pipiens and Culex territans, an an intermediate host, the northern leopard frog (Rana pipiens). Parasitol. Res. 80: 559-568.

Telford JR. S.R. 2009: Hemoparasites of the Reptilia. CRC Press, Taylor and Francis Group, Boca Raton, Florida, 376 pp.

Telford JR. S.R. 2010: Three new Hepatozoon species (Apicomplexa: Hepatozoidae) infecting the Florida kingsnake, Lampropeltis getula floridana. J. Parasitol. 96: 162-169.
Telford Jr. S.R., Butler J.F., Telford R.S. 2002a: Hepatozoon species (Apicomplexa: Hepatozoidae) of the corn snake, Elaphe guttata (Serpentes: Colubridae) and the pigmy rattlesnake, Sistrurus miliarius barbouri (Serpentes: Viperidae) in south Florida. J. Parasitol. 88: 778-782.

Telford JR. S.R., Butler J.F., Telford R.S. 2005: Hepatozoon polytopis $\mathrm{n}$. sp. parasitic in two genera and species of colubrid snakes in southern Florida. J. Parasitol. 91: 144-147.

Telford Jr. S.R., Ernst J.A., Clark A.M., Butler J.F. 2004: Hepatozoon sauritus: a polytopic hemogregarine of three genera and four species of snakes in northern Florida, with specific identity verified from genome analysis. J. Parasitol. 90: 352-358.

Telford Jr. S.R., Moler P.E., Butler J.F. 2008: Hepatozoon species of the timber rattlesnake in northern Florida: description of a new species, evidence of salivary gland oocysts, and a natural cross-familial transmission of an Hepatozoon species. J. Parasitol. 94: 520-523.

Telford JR. S.R., Telford S.R. III, Butler J.F. 2002b: The status of Haemogregarina mansoni Sambon and Seligmann from $\mathrm{Za}$ menis flagelliformis Laurenti. J. Parasitol. 88: 783-785.

TELFord JR. S.R., WozNiaK E.J., ButLER J.F. 2001: Haemogregarine specificity in two communities of Florida snakes, with descriptions of six new species of Hepatozoon (Apicomplexa: Hepatozoidae) and a possible species of Haemogregarina (Apicomplexa: Haemogregarinidae). J. Parasitol. 87: 890-905.

Utiger U., Helfenberger N., Schatti B., Schmidt C., Ruf M., ZISWILER V. 2002: Molecular systematics and phylogeny of Old and New World ratsnakes, Elaphe auct., and related genera (Reptilia, Squamata, Colubridae). Russian J. Herpetol. 9: $105-124$. 